\title{
Temporal persistence in the vertical structure of the assemblage of planktonic medusae in the NW Mediterranean Sea
}

\author{
Emmanuelle Buecher ${ }^{1,2, *}$, Mark J. Gibbons ${ }^{2}$ \\ ${ }^{1}$ Laboratoire d'Océanographie biologique et Écologie du Plancton marin, CNRS/UPMC 7076, Station zoologique, \\ BP 28, 06234 Villefranche-sur-Mer, France \\ ${ }^{2}$ Zoology Department, University of the Western Cape, Private Bag X17, 7535 Bellville, South Africa
}

\begin{abstract}
The seasonal occurrence and vertical distribution of planktonic cnidarians (hydromedusae and scyphomedusae) were investigated over a 2 yr period in the Bay of Villefranche-sur-Mer A total of 37 species were recorded, of which the meroplanktonic species were more specific and the holoplanktonic species were more abundant. The results suggest that although medusae were everpresent in the bay, the assemblage changed through time. These changes reflected species-specific responses to the environment and were linked to the thermal structure of the water column: the meroplanktonic species were most common during eutrophic periods of the year while the holoplanktonic species were present throughout the year. The dominant species of medusae partitioned vertical space and each occupied a characteristic depth. This segregation in the vertical dimension was maintained in the different seasons despite the fact that the exact species changed. It is suggested that the strong degree of structure to the medusoid assemblage in the Bay of Villefranche-sur-Mer might reflect the stability and age of the Mediterranean ecosystem.
\end{abstract}

KEY WORDS: Medusae - Vertical distribution - Seasonality Mediterranean Sea A Assemblage structure

\section{INTRODUCTION}

Zooplankton assemblages in oligotrophic and oceanic waters display a constancy of structure that spans many kilometers in distance and years in time (McGowan \& Walker 1979). This constancy reflects the great age of these systems and their relative physical stability, and may have allowed organisms to evolve mechanisms of co-existence (Sanders 1968). This structure may be encouraged in the vertical dimension by the physical, layered nature of the ocean, which allows organisms to partition vertical space (Longhurst 1985). While there is some evidence to support the tenet of vertical partitioning amongst crustaceans (Ambler \& Miller 1987, Flock \& Hopkins 1992) and fishes (Hopkins \& Gartner 1992), evidence from older

\footnotetext{
·E-mail: ebuecher@sfri2.wcape.gov.za
}

planktonic taxa is less abundant (Gili et al. 1987, Mackie et al. 1987).

By contrast, zooplankton assemblages in nutrientenriched coastal and upwelling areas are very variable in their composition and structure (e.g. Gibbons \& Hutchings 1996). This must in part reflect the physically dynamic nature of the coastal and shelf environments, and the instability of the vertical dimension which effectively prevents the evolution of mechanisms of co-existence. Hutchinson (1961) argued that the temporal scale of the physical event is most important in influencing the structure and diversity of planktonic assemblages. When this is shorter than the generation times of the plankton, then biological 'accommodation' between species becomes difficult. Plankton assemblages are influenced by a plethora of physical factors which encourage mixing and include, for example, internal waves, shelf waves, tidal currents, coastal upwelling currents and offshore advec- 
tion, and are also influenced by the depth of their environment, especially in shallow waters. Although there may be some pattern of predictability to daily features (and hence there is the possibility for biological mechanisms of co-existence to evolve, e.g. Gibbons 1994), the magnitude and persistence of many features vary on a less predictable (including seasonal) scale.

Although zooplankton assemblages of oceanic and coastal environments are structured in different ways, our understanding of their structure in environments which are less physically extreme is poor. Here, we examine the vertical structure of 'ancient' planktonic organisms in an essentially oligotrophic body of water, which is nevertheless strongly seasonal in its physical characteristics. This information sheds light on our understanding of planktonic assemblages in such areas, and contributes to our knowledge of the evolution of assemblages of planktonic cnidarians.

\section{MATERIALS AND METHODS}

Study area. The Bay of Villefranche-sur-Mer is a sheltered embayment near Nice, in the Ligurian Sea. It is typical of the inshore waters of the NW Mediterranean, and the hydrology is influenced by the Ligurian Current and local winds (Gostan 1968, Béthoux et al. 1988). The Ligurian Current lies close inshore and runs westward along the French coast. A branch of surface waters enters the eastern side of the bay at Cap Ferrat, and leaves at a depth of $\sim 50$ to $100 \mathrm{~m}$ on the western side at the Cape of Nice.

Field sampling. All the hydrological data and the zooplankton samples were collected in $87 \mathrm{~m}$ of water at the entrance to the Bay of Villefranche-sur-Mer (Stn B: $43^{\circ} 41^{\prime} 10^{\prime \prime} N, 7^{\circ} 19^{\prime} 00^{\prime \prime} E$ ). Hydrological measurements have been taken at Stn B each week since 1957 as part of an ongoing monitoring program, and full details have been provided by Etienne et al. (1991). Between the months of June and December 1994, vertical temperature profiles of the water column were established from data collected at the same time by $a$ Micrel ${ }^{\text {it }}$ sensor attached to the zooplankton net. From January 1995 to January 1996, temperature and salinity measurements were taken continuously throughout the water column $(80$ to $0 \mathrm{~m})$ with a CTD Sea Cat Profiler

Zooplankton samples were collected once a week between 08:30 and 11:00 h, from January 1994 to January 1996, using a closing Regent net. This net (diameter of mouth aperture $1.0 \mathrm{~m}$, filtering length of $4.0 \mathrm{~m}$, mesh size 680 to $700 \mu \mathrm{m}$, silk tissue type $\mathrm{n}^{\circ} 00$ ) is well suited for sampling soft-bodied organisms, because they roll on the smooth silk with minimal tissue damage.
The net was towed horizontally for $10 \mathrm{~min}$ at 6 different depths $(10,20,30,40,50$ and $60 \mathrm{~m})$, before being closed remotely prior to retrieval. The volume filtered by each net was about $260 \mathrm{~m}^{3}$. The depth of the net was controlled in real time by a Micrel ${ }^{*}$ sensor fitted near its aperture.

Upon retrieval the samples were immediately preserved in $4 \%$ seawater formalin. All medusae (hydromedusae and scyphomedusae) were identified and counted within $2 \mathrm{~h}$ following their capture, without subsampling. A total of 556 samples were counted during this 2 yr survey.

Numerical and statistical analysis. Descriptive, multivariate statistics were used to examine relationships among weekly samples, in order to see whether assemblages changed through the course of the study period. The data collected in 1994 and 1995 have been treated separately in an effort to avoid spurious results caused by episodic species, and in an attempt to determine whether patterns in one year were repeated in another. All species that occurred in less than $10 \%$ of any year's samples have been ignored. The stratified densities of the dominant species were then integrated to provide weekly estimates of their abundance. These data were then root-root transformed and a similarity matrix was constructed using the Bray-Curtis Index (Field et al. 1982). These matrices were used to plot classification diagrams of percentage similarity between weekly samples using group-average sorting.

In order to determine seasonal patterns of association amongst the dominant species, the cluster analysis procedure was also repeated using the species rather than sample data. These analyses were conducted using Primer software (Clarke \& Warwick 1994).

The relationships between the abundance of the dominant species and temperature and salinity were examined using a multiple regression analysis (MRA) of the untransformed stratified data. Relationships between the vertical distribution of the dominant species (as weighted mean depth [WMD]; Roe et al. 1984) and the physical structure of the water column were examined using correlation analyses. Water column structure was parametised as sea surface temperature, mean water column temperature, the depth of the $19^{\circ} \mathrm{C}$ isotherm $\left(19^{\circ} \mathrm{C}\right.$ median temperature $)$ and $\Delta \mathrm{T} / \Delta \mathrm{Z}$ (which is the temperature difference between the sea surface and $80 \mathrm{~m}$ depth), as well as sea surface salinity and $\Delta S / \Delta Z$. Tests of significance between the WMD of the different medusae were carried out using the Mann-Whitney $U$-test. This is a non-parametric test and was chosen because of sometimes large differences in sample size. All these analyses were conducted using Statistica software. 
Fig. 1. Vertical profiles of temperdture and salinity in the Bay of Villefranche-sur-Mer during 1994 and 1995. (A) Data from 7 June 1994;

(B) data from 12 January 1995
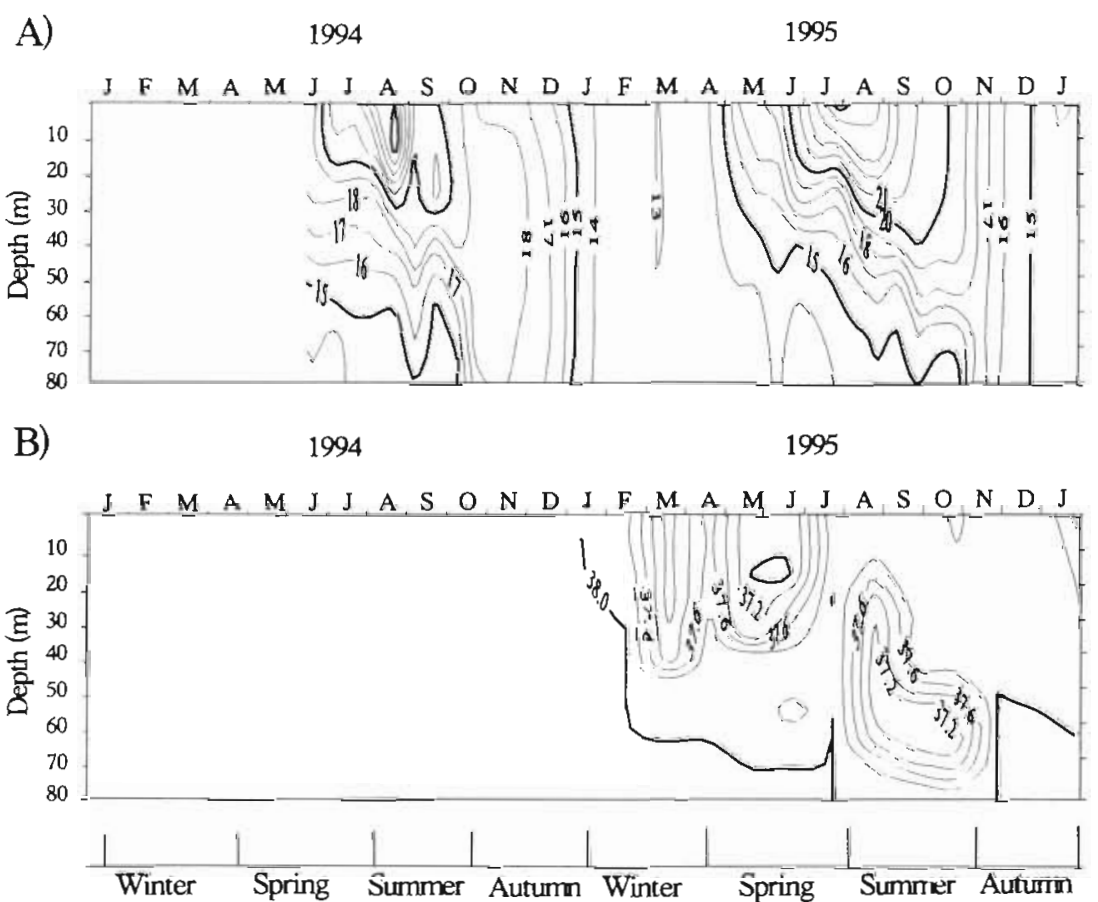

\section{RESULTS}

\section{Physical environment}

Four hydrological seasons could be identified on the basis of the structure and properties of the water column (Fig. 1). During the hydrological winter, which extended from mid-January to early April, the water column was isothermal $(\Delta T / \Delta Z$ was minimal and sea surface temperature $[S S T]<14^{\circ} \mathrm{C}$ ) and isohaline $(\Delta \mathrm{S} / \Delta \mathrm{Z}<0.3 \%)$. The hydrological spring extended from mid-April to August, and was characterized by the establishment of a thermohaline stratification (progressive increase in $\Delta T / \Delta Z$, and $\Delta S / \Delta Z>0.5 \%$ ). At the beginning of the hydrological summer (August), the thermal stratification was maximal $\left(\Delta \mathrm{T} / \Delta \mathrm{Z}>10^{\circ} \mathrm{C}\right)$. As the season extended (until mid-October in 1994 and mid-November in 1995), a slow cooling of the sea surface temperature and a warming at depth were observed. The hydrological autumn began when the water column became isothermal $\left(\Delta \mathrm{T} / \Delta \mathrm{Z}<2^{\circ} \mathrm{C}\right)$ and isohaline $(\Delta S / \Delta Z<0.4 \%)$ and continued until the water reached $14^{\circ} \mathrm{C}$

\section{Medusae}

Although a total of 35 species of hydromedusae and 2 scyphomedusae were identified over the 2 yr isee Table 1), only 13 species could be considered abun- dant. The anthomedusae were most diverse (20 species) but were only represented by a few individuals that were collected for (generally) a short period of time in spring (e.g. Lizzia blondina or Steenstrupia nutans). The leptomedusae ( 6 species) were numerous during spring (e.g. Obelia spp.), and from the end of summer to the beginning of autumn (e.g. Clytia mccradyi), and accounted for $\sim 25 \%$ of total abundance. The 4 species of trachymedusae represented more than $60 \%$ of the total number of medusae. They were especially numerous during autumn and winter in the upper $40 \mathrm{~m}$. Solmundella bitentaculata was the most common species of the 4 narcomedusae, and occurred for short periods during summer. Scolionema suvaense was the only species of limnomedusa, and only 2 individuals were collected (14 June and 27 July 1995). Pelagia noctiluca (semaeostomae) and Nausitho punctata (coronatae) were the 2 scyphomedusae collected in the bay especially in spring and summer.

\section{Seasonality}

\section{Assemblages}

Two main groups of medusae could be distinguished from the cluster analysis during 1994 and 1995 (Fig. 2) These corresponded to samples collected when the water column was either strongly stratified and warm (Group I), or isothermal and cold (Group II). The 2 clus- 


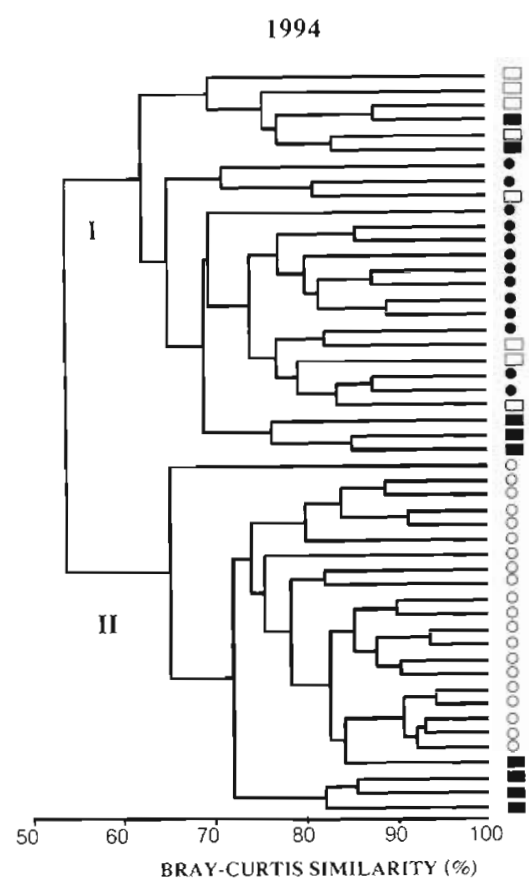

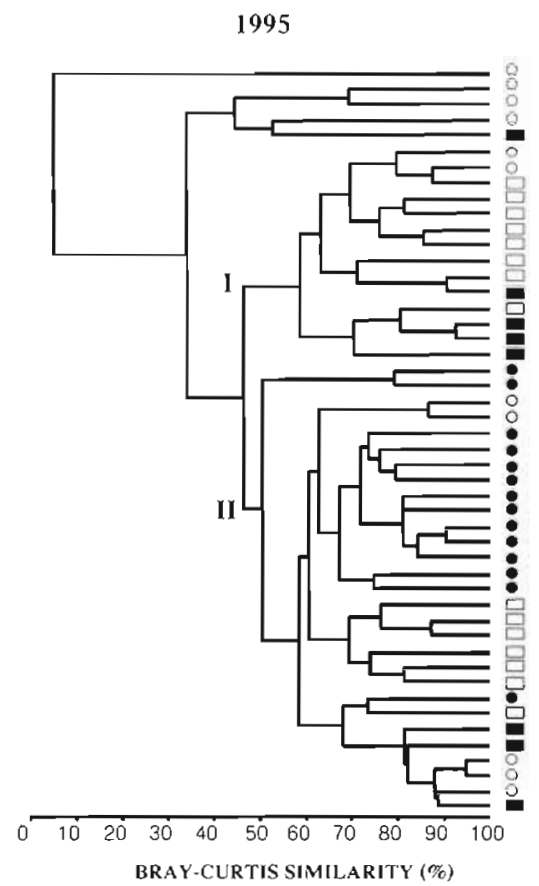

Fig. 2. Percentage of similarity between weekly samples collected at Stn B, in the Bay of Villefranche-sur-Mer during 1994 and 1995. Group I clusters samples collected during periods when the water column was warm or when it was strongly stratified. Group II clusters samples collected when the water column was isothermal and cool. Samples identified by hydrological season only: (o) Winter, (•) Spring, (口) Summer, Autumn

ters were $\sim 55 \%$ similar in 1994 and $\sim 45 \%$ similar in 1995. Samples collected in any one season tended to be most closely grouped with other samples collected during the same season, although there was some overlap between samples collected in adjacent seasons.

\section{Species}

During 1994 and 1995, 2 distinct groups of species could be discerned from the results of the cluster analyses (Fig. 3). Although there were some differences between the precise make-up of the groups each year (principally involving meroplanktonic species), the clusters roughly correspond to those medusae which were either present for much of the year (Group A), or were present only for short periods of each year, especially when the water column was cold and less stratified (Group B). While the species that comprised Group B were from different taxa, this was not the case with Group A. The differences between 1994 and 1995 in the composition of the 2 groups can largely be attributed to the appearance of episodic species such as Laodicea undulata (which was sporadically collected during 1994) or Clytia mccradyi (which attained very high densities in summer, and in early autumn 1994).

Most of the species that comprised Group B were generally absent from the summer months (Table 1), and they displayed generally similar, negative responses to the thermal environment (Table 2a). By con- trast, the species that comprised Group A were variably correlated with some aspect of the thermal environment (Table 2a). For example, the abundance of both Aglaura hemistoma and Solmundella bitentaculata was positively correlated with temperature, while Persa incolorata was negatively correlated with temperature (Table 2a).

\section{Vertical distribution and abundance}

Each of the dominant medusae within an identified seasonal grouping (A or B) had a WMD (Table 1) which was significantly different (Table 3) from that of other species in the same seasonal group. In cases where species have WMDs that overlap, the taxa are from different classes or orders. Otherwise, the specific identification was approximate (Obelia spp.), or the number of observations was low (Rathkea octopunctata; Table $2 b)$. Note that instances of overlap were greater amongst Group B species than Group A species.

The coefficients of variation associated with the WMDs were generally less than $50 \%$ for all species except Pelagia noctiluca (Table 1). The results of the correlation analysis between WMD and various parameters of the physical environment (Table 2 b) seem to indicate that at least some of this variability can be accounted for by species-specific responses to temperature (but not salinity). In other words, some species appeared to change their vertical distribution with seasonal fluctuations in their physical environment. 
1994

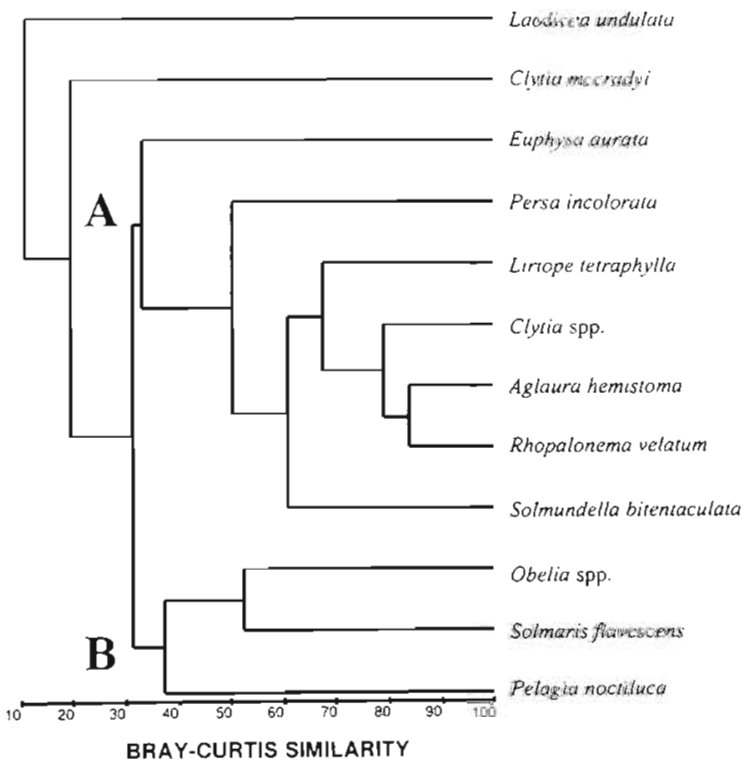

1995

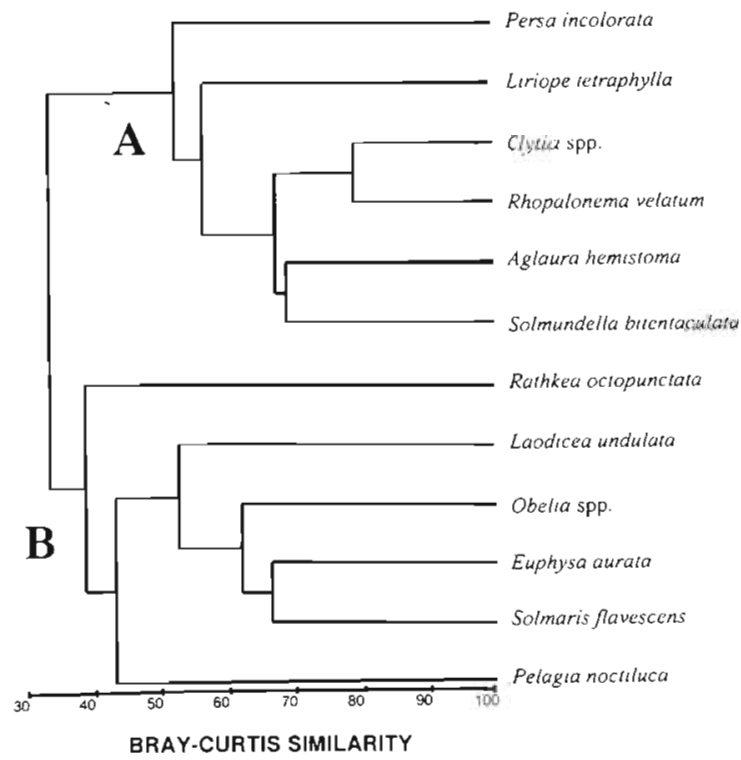

Fig. 3. Percentage of similarity between dominant medusae in 1994 and 1995. Group A species were present through much of each year, while Group B species only occurred for relatively short periods of time each year

\section{DISCUSSION}

Although all of the species of medusae collected during the present study have previously been reported from the NW Mediterranean (Vives 1966, Goy 1972, Brinkmann-Voss 1987, Gili et al. 1987), the novelty of the data lies in their treatment here as assemblages. The results demonstrate that there are 2 clear assem- blages present throughout the year and that these are associated with either a stratified or an isothermal water column (similar observations were made by Gili et al. [1987] for individual species). The changeover between assemblages was not absolute and instantaneous, as evidenced, for example, by the clustering of some spring samples with either winter or (but not, and) summer samples (Fig. 2). This implies that species changes were relatively gradual, and probably reflected the gradual changes in the physical environment.

The 2 seasonal assemblages (Fig. 2) were not clearly mirrored by the 2 groups of species identified from the cluster analyses (Fig. 3), which were largely differentiated on whether the species were present for prolonged or discrete periods each year. Some of the species (especially those belonging to Group A) were present as part of both the seasonal assemblages identified (Fig. 2). While it is tempting to suggest that the species grouped together because they were either steno- or eurythermal, it should be noted that the degree of similarity between the species within the groups (Fig. 3) was generally low. Consequently, similarities in individual species responses to the physical environment for species which clustered together were also low. This is supported by the results of the MRA in Table $2 \mathrm{a}$, which suggests that while some of the holoplanktonic members of Group A were positively correlated with temperature, the meroplanktonic species were generally negatively correlated with temperature. By contrast, the species in Group B were mostly negatively correlated with some aspect of the thermal environment (Table 2a) and congruence with seasonal Group II (Fig. 2) can readily be interpreted. The identity of the species groups themselves, therefore, seems to depend upon persistence per se, which in the case of the meroplanktonic members in Group $A$ is probably due to pulsed recruitment rather than maintenance.

This being said, a species which was negatively associated with temperature could be present in months when the SST was warm and the water column was well stratified by modifying its vertical distribution. The daytime WMD of some of the species was influenced by some aspect of the physical environment (Table 2b), which implies that they changed their vertical distribution through the course of the year. For example, Persa incolorata was found throughout the cold isothermal water column in winter but occurred in deeper water (down to $30 \mathrm{~m}$ ) upon stratification. It avoided temperatures higher than $19^{\circ} \mathrm{C}$. Goy (1987) previously observed the same behaviours in $P$. incolorata in the Ligurian Sea, which she termed summer submergence.

Variations in the specific composition of the 2 seasonal groups ( $\mathrm{A}$ or $\mathrm{B}$ ) in the Bay of Villefranche-sur- 
Mer between 1994 and 1995 were relatively small and largely reflected the presence or absence of episodic meroplanktonic species. Such differences are to be expected in any body of water under the influence of currents etc., and can in part be explained by slight changes in the origin and timing of seasonal events. The specific composition of the 2 seasonal groups clearly reflected the life history strategies of the different medusae. The persistent species in Group A were mostly holoplanktonic, and it has been suggested that their daily energy requirements are lower than those of meroplanktonic species (Goy 1997). However, it is unknown if local population maintenance is effected through a long generation time, because some holoplanktonic species may pass through several generations each year (Arai 1992, Buecher et al. 1997). The meroplanktonic member of Group A, Clytia spp., probably comprises a number of species (there are 7 species of Clytia known in the Mediterranean Sea but only 3 are budding hydroids, Picard 1958), each with slightly different environmental requirements. The species in seasonal Group B, by contrast, were mostly mero-

Table 1. List of medusae recovered from Stn B, in the Bay of Villefranche-sur-Mer, during 1994 and 1995. Also shown is the taxon to which each belongs (hydromedusae $=$ A: Anthomedusae; L: Leptomedusae; Li: Limnomedusae; T: Trachymedusae; N: Narcomedusae; scyphomedusae = C: Coronatae; Se: Semaeostomae), the total number of individuals recovered, and the weighted mean depth (WMD) or the range over which most individuals were collected. Coefficient of variation (CV) about the WMD is also shown as a percentage where applicable (na: not applicable). Seasonality by calendar month (") is also presented. Species in bold are holoplanktonic, the others are meroplanktonic

\begin{tabular}{|c|c|c|c|c|c|c|c|c|c|c|c|c|c|c|c|c|}
\hline Species & Taxon & Total & WDM $(\mathrm{m})$ & $\mathrm{CV}$ & $\mathrm{J}$ & $\mathrm{F}$ & $\mathrm{M}$ & A $N$ & $\mathrm{M} \mathrm{J}$ & $\mathrm{J}$ & $\mathrm{J}$ & $A$ & $S$ & $\mathrm{O}$ & $\mathrm{N}$ & $\mathrm{D}$ \\
\hline \multicolumn{17}{|l|}{$10-30 \mathrm{~m}$} \\
\hline Liriope tetraphylla (Chamiso \& Eysenhardt 1821) & $\mathbf{T}$ & 2434 & 22 & 46 & $\cdot$ & • & $\cdot$ & $\cdot \cdot$ & - $\cdot$ & - & & & & • $\cdot$ & • & $\cdot$ \\
\hline Solmissus albescens (Gegenbaur 1856) & $\mathbf{N}$ & 3 & $10-30$ & na & & • & & & & & & & & & & \\
\hline Cunina sp. & $N$ & 5 & $10-30$ & na & & & $\cdot$ & & & & & & & & & \\
\hline Rathkea octopunctata (M. Sars 1835) & A & 450 & 20 & 29 & & & $\cdot$ & $\cdot \cdot$ & • & & & & & & & \\
\hline Laodicea undulata (Forbes \& Goodsir 1851) & $\mathrm{L}$ & 139 & 30 & 43 & & & • & $\cdot \cdot$ & • & & & & & & & \\
\hline Pelagia noctíluca (Forskal 1775) - ephyra & Se & 7968 & 15 & 103 & & & $\cdot$ & $\cdot \cdot$ & · $\cdot$ & & • & $\cdot$ & & & & \\
\hline Dipurena ophiogaster (Haeckel 1879) & A & 22 & 10 & na & & & & $\cdot \cdot$ & - $\cdot$ & & & & & & & \\
\hline Sarsia tubulosa (M. Sars 1835) & A & 3 & $10-30$ & na & & & & $\cdot \cdot$ & $\cdot \cdot$ & & & & & & & \\
\hline Lizzia blondina (Forbes 1848) & A & 9 & $10-30$ & na & & & & $\cdot \cdot$ & - $\cdot$ & & & & & & & \\
\hline Nausithœe punctata (Kölliker 1853) & $\mathrm{C}$ & 50 & $10-30$ & na & & & & & - $\cdot$ & & • & • & • & - $\cdot$ & • & $\cdot$ \\
\hline Solmundella bitentaculata (Quoy \& Gaimard 1833) & $\mathbf{N}$ & 1467 & 24 & 52 & & & & & " • & & - & " & • & * & & \\
\hline Clytia mccradyi (Brooks 1888) & $\mathrm{L}$ & 452 & 10 & 45 & & & & & & & & • & • & • & • & \\
\hline \multicolumn{17}{|l|}{$30-60 \mathrm{~m}$} \\
\hline Persa incolorata (McCrady 1857) & $\mathrm{T}$ & 468 & 41 & 32 & $\cdot$ & · & $\cdot$ & $\cdot \cdot$ & $\cdot \cdot$ & & • & - & - & • & • & • \\
\hline Euphysa aurata (Forbes 1848) & A & 242 & 44 & na & & & $\cdot$ & $\cdot \cdot$ & - $\cdot$ & & & & & & & \\
\hline Merga tregoubovii (Picard 1961) & A & 1 & 60 & na & & & & $\cdot$ & & & & & & & & \\
\hline Leuckartiara nobilis (Hartlaub 1913) & A & 71 & $30-60$ & na & & & & $\cdot \cdot$ & - & & & & & & & \\
\hline Solmaris flavescens (Kölliker 1853) & $\mathbf{N}$ & 175 & 35 & 37 & & & & $\cdot \cdot$ & - $\cdot$ & " & & & & . & & \\
\hline Leuckartiara octona (Fleming 1823) & A & 8 & $30-60$ & na & & & & $\cdot \cdot$ & - $\cdot$ & • & • & & & & & \\
\hline Amphinema dinema (Péron \& Lesueur 1810) & A & 16 & 60 & na & & & & $\cdot$ & & • & & - & & & & \\
\hline Eutima gegenbauri (Haeckel 1864) & $\mathrm{L}$ & 47 & $30-60$ & na & & & & $\cdot \cdot$ & - $\cdot$ & • & • & - & & & & \\
\hline Zanclea costata (Gegenbaur 1856) & A & 94 & $30-60$ & na & & & & & - $\cdot$ & • & • & $\cdot$ & & & & \\
\hline Podocoryne minima (Trinci 1903) & A & 14 & $30-60$ & na & & & & & & • & • & $\cdot$ & & & & \\
\hline Bougainvillia ramosa (van Beneden 1844) & A & 3 & $30-60$ & na & & & & & & • & • & $\cdot$ & & & & \\
\hline Scolionema suvaense (Agassiz \& Mayer 1899) & $\mathrm{Li}$ & 2 & $30-60$ & na & & & & & $\cdot$ & • & • & & & & & \\
\hline Koellikenina fasciculata (Péron \& Lesueur 1810) & A & 2 & $30-60$ & na & & & & & & & • & & & & & \\
\hline Amphinema rugosum (Mayer 1900) & A & 1 & $30-60$ & na & & & & & & & • & & & & & \\
\hline Sarsia gemmifera (Forbes 1848) & A & 11 & $30-60$ & na & & & & & & & • & • & & & & \\
\hline Sarsia eximia (Allman 1859) & A & 1 & $30-60$ & na & & & & & & & & • & & & & \\
\hline Eucheilota paradoxida (Mayer 1900) & $\mathrm{L}$ & 4 & $30-60$ & na & & & & & & & & • & & & & \\
\hline Sarsia prolifera (Forbes 1848) & A & 1 & 60 & na & & & & & & & & • & & & & \\
\hline \multicolumn{17}{|l|}{$0-60 \mathrm{~m}$} \\
\hline Clytia spp. & L & 5804 & 30 & 32 & • & • & • & $\cdot \cdot$ & • " & & & & & " & • & • \\
\hline Podocoryne areolata (Alder 1832) & A & 53 & $10-60$ & na & & • & • & & & & & & & & & \\
\hline Obelia spp. & $\mathrm{L}$ & 297 & 27 & 51 & & & $\cdot$ & $\cdot \cdot$ & • & & & & & • & • & \\
\hline Aglaura hemistoma (Péron \& Lesueur 1810) & $\mathrm{T}$ & 9279 & 26 & 43 & & & & & • $\cdot$ & & 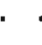 & • & • & - & • & \\
\hline Rhopalonema velatum (Gegenbaur 1856) & $\mathrm{T}$ & 5128 & 27 & 39 & & & & $\cdot \cdot$ & - $\cdot$ & & · & . & • & • & " & \\
\hline Podocoryne carnea (M. Sars 1835) & A & 22 & $10-60$ & na & & & & $\cdot \cdot$ & - $\cdot$ & & $\cdot$ & • & & & & \\
\hline Steenstrupia nutans (M. Sars 1835) & A & 42 & $10-60$ & na & & & & & $\cdot \cdot$ & & & & & & & \\
\hline
\end{tabular}


Table 2. (a) The relationships between the density of each of the dominant species of medusae and salinity and temperature, as determined by multiple regression analysis (MRA). Species in seasonal Group A indicated ( $\left.{ }^{a}\right)$. The significance of individual parameters, and the overall model is shown $\cdot(p<0.05)$. Data derived from individual net tows, the number of samples $=275$ in all instances. (b) Correlation matrix between the weighted mean depth of each medusa species (Table 1), and the various parameters used to describe the structure of the water column. Significant $(p<0.05)$ correlations only are shown. $N$ (number of observations) is shown in each instance. $\mathrm{n} / \mathrm{s}$ : not significant

\begin{tabular}{|c|c|c|c|c|c|c|}
\hline \multicolumn{2}{|l|}{$\begin{array}{l}\text { (a) } \\
\text { Species }\end{array}$} & Salinity & Temperature & \multicolumn{2}{|c|}{ Model } & SST \\
\hline S. bitentaculata ${ }^{\mathrm{a}}$ & \multicolumn{2}{|c|}{-0.76} & $0.19^{\circ}$ & \multicolumn{2}{|c|}{ - } & - \\
\hline L. tetraphylla a & \multicolumn{2}{|c|}{-1.32} & $-0.19^{\circ}$ & \multicolumn{2}{|c|}{ - } & -0.43 \\
\hline A. hemistoma ${ }^{a}$ & \multirow{2}{*}{\multicolumn{2}{|c|}{$\begin{array}{l}-2.13 \\
-8.37\end{array}$}} & $1.46^{\circ}$ & \multicolumn{2}{|c|}{$\cdot$} & - \\
\hline R. velatum ${ }^{\mathrm{a}}$ & \multirow{2}{*}{\multicolumn{2}{|c|}{$\begin{array}{l}-8.37^{\circ} \\
-7.71^{\circ}\end{array}$}} & -0.25 & \multicolumn{2}{|c|}{$\cdot$} & - \\
\hline Clytia spp. & & & $-0.47^{\circ}$ & \multicolumn{2}{|c|}{$\cdot$} & 0.27 \\
\hline$P$. incolorata ${ }^{a}$ & \multicolumn{2}{|c|}{0.33} & $-0.08^{\circ}$ & \multicolumn{2}{|c|}{ - } & 0.54 \\
\hline$P$. noctiluca & \multicolumn{2}{|c|}{-30.32} & -2.81 & \multicolumn{2}{|c|}{$\mathrm{n} / \mathrm{s}$} & - \\
\hline R. octopunctata & \multicolumn{2}{|c|}{-1.81} & -0.19 & \multicolumn{2}{|c|}{$\mathrm{n} / \mathrm{s}$} & - \\
\hline Obelia spp. & \multicolumn{2}{|c|}{$-0.66^{\circ}$} & -0.03 & \multirow{2}{*}{\multicolumn{2}{|c|}{$\dot{.}$}} & - \\
\hline L. undulata & \multicolumn{2}{|c|}{-0.43} & $-0.04^{\bullet}$ & & & 0.70 \\
\hline S. flavescens & \multicolumn{2}{|c|}{-0.34} & -0.05 & & & - \\
\hline E. aurata & & & $-0.06^{\circ}$ & & & 0.63 \\
\hline (b) & & & & & & \\
\hline Species & Mean temperature & $\Delta T / \Delta Z$ & Depth $19^{\circ} \mathrm{C}$ isotherm & Mean salinity & $\Delta \mathrm{T} / \Delta \mathrm{S}$ & $N$ \\
\hline S. bitentaculata ${ }^{\mathrm{a}}$ & - & - & - & - & -- & 31 \\
\hline L. tetraphylla $a^{a}$ & -0.36 & - & - & - & - & 31 \\
\hline A. hemistoma & - & - & - & - & - & 38 \\
\hline R. velatum ${ }^{a}$ & - & - & - & - & - & 40 \\
\hline Clytia spp. ${ }^{a}$ & - & - & - & - & - & 46 \\
\hline P. incolorata ${ }^{\mathrm{a}}$ & 0.54 & - & 0.40 & - & - & 24 \\
\hline P. noctiluca & - & - & - & - & - & 12 \\
\hline R. octopunctata & - & - & - & - & - & 4 \\
\hline Obelia spp. & - & -0.35 & - & - & - & 22 \\
\hline L. undulata & 0.76 & 0.66 & - & - & - & 13 \\
\hline S. flavescens & - & - & - & - & - & 17 \\
\hline E. aurata & 0.61 & - & 0.48 & - & - & 17 \\
\hline
\end{tabular}

Table 3. Adjusted Z statistic (numbers in bold) and its significance in Mann-Whitney $U$-tests between the WMD of medusae in Group A and Group B. $\cdot$ : significant at $p<0.05, \mathrm{n} / \mathrm{s}$ : not significant

\begin{tabular}{|c|c|c|c|c|c|c|c|}
\hline $\begin{array}{l}\text { Group A } \\
\text { species }\end{array}$ & S. bitentaculata & \multicolumn{2}{|c|}{ L. tetraphylla } & A. hemistoma & R. velatum & Clytia spp. & P. incolorata \\
\hline S. bitentaculata & & 0. & 1. & & 2.3 & 3.9 & 6.2 \\
\hline L. tetraphylla & $\mathrm{n} / \mathrm{s}$ & & 2. & & 3.0 & 5.1 & 6.9 \\
\hline A. hemistoma & $\mathrm{n} / \mathrm{s}$ & * & & & 0.7 & 2.7 & 6.2 \\
\hline$R$. velatum & $\cdot$ & • & $n$ & & & 2.0 & 6.1 \\
\hline Clytia spp. & • & · & • & & $\cdot$ & & 5.7 \\
\hline P. incolorata & $\cdot$ & * & • & & $\cdot$ & • & \\
\hline $\begin{array}{l}\text { Group B } \\
\text { species }\end{array}$ & C. mccradyi & P. noctiluca & R. octopunctata & Obelia spp. & L. undulata & S. flavescens & E. aurata \\
\hline C. mccradyi & & 0.3 & 2.2 & 3.6 & 3.5 & 4.1 & 4.5 \\
\hline P. noctiluca & $\mathrm{n} / \mathrm{s}$ & & 1.5 & 3.6 & 3.3 & 4.1 & 5.1 \\
\hline R. octopunctata & • & $\mathrm{n} / \mathrm{s}$ & & 1.0 & 1.5 & 2.3 & 2.9 \\
\hline Obelia spp. & . & $\cdot$ & $\mathrm{n} / \mathrm{s}$ & & 0.9 & 2.4 & 5.1 \\
\hline L. undulata & - & - & $\mathrm{n} / \mathrm{s}$ & $\mathrm{n} / \mathrm{s}$ & & 0.3 & 3.5 \\
\hline S. flavescens & • & $\cdot$ & $\cdot$ & $\cdot$ & $\mathrm{n} / \mathrm{s}$ & & 2.8 \\
\hline E. aurata & $\cdot$ & $\cdot$ & $\cdot$ & $\cdot$ & $\cdot$ & $\cdot$ & \\
\hline
\end{tabular}




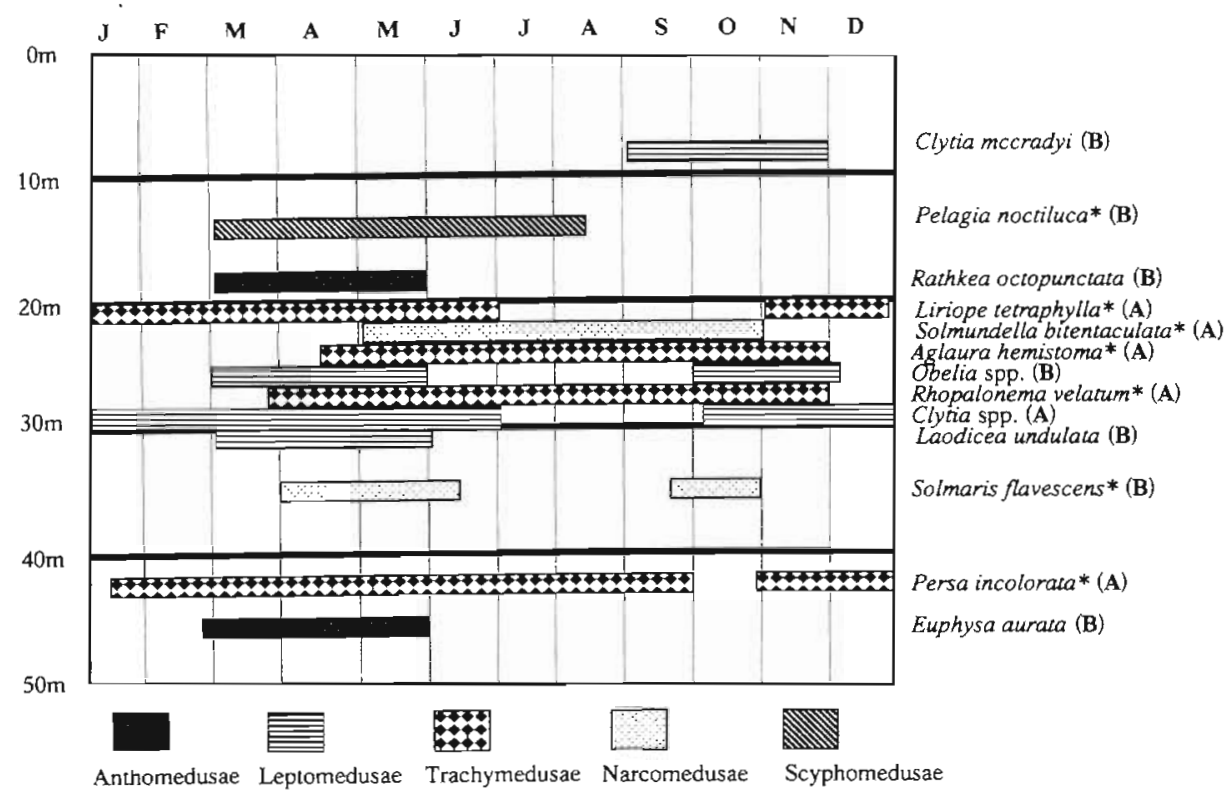

Fig. 4. Temporal and spatial patterns of distribution of the dominant medusae in the different seasonal groups (Groups A and B) in the Bay of Villefranche-sur-Mer. "Holoplanktonic species planktonic and peaked in numbers during spring and autumn. This can be explained by the fact that their occurrence in the plankton is strictly dependent on the budding period of their polyps, which is thought to be primarily controlled by temperature and food availability (Werner 1958, 1961, Zelickman 1972, Brewer \& Feingold 1991). Their abundance in early spring (anthomedusae) and again in autumn (leptomedusae), coincides with the onset of surface warming and with the breakdown of summer stratification, respectively. These 2 periods can be considered as 'eutrophic' for this bay, and appeared some 2 mo after the highest nitrate concentrations were observed (Buecher 1996). The time lag between high nutrient concentration and the peak occurrence of gelatinous carnivores is probably a function of the successive appearance of the different trophic levels in the pelagic food web. Meroplanktonic species seem to be very sensitive to these environmental variations (Arai 1992), especially to temperature and prey abundance (Buecher \& Gasser 1998), and such variations can lead to their pulsed appearance.

The species-specific responses in WMD to the physical environment, coupled with the generally different WMD of each species, can be interpreted as allowing the assemblage to partition vertical space amongst members throughout the year. This can be most clearly seen in the schematic Fig. 4, which indicates that where species have similar WMDs, they are either from different assemblages (and occur at different times of the year) or they are from quite different taxonomic groups. This latter point is important, because it has been suggested that members of different medusoid orders are unlikely to feed on the same prey (Purcell \& Mills 1988, Mills 1995).
It is being shown with increasing frequency that pelagic assemblages in oceanic environments exhibit some sort of biological structure, presumably as a result of the forces of historic competition. In the eastern Gulf of Mexico, myctophid fishes and natantid decapods partition depth and food amongst assemblage members (Hopkins \& Gartner 1992, Flock \& Hopkins 1992), whilst in the North Pacific gyre, congeneric copepods have been shown to partition depth (Ambler \& Miller 1987). Euphausiids in the equatorial Pacific Ocean also appear to partition feeding and depth (Roger 1973, 1975), as they also do at the stable oceanic front off northern Namibia (Barange et al. 1991). All these ecosystems are characterised either by great age, or by physical stability. Although the assemblages tend to be diverse and the food chains are relatively long, the biomass of phytoplankton upon which the systems are based is generally low (Longhurst 1995). Consequently, the potential for interspecific competition for food resources amongst assemblage members is likely to be large (in the absence of compensatory processes such as predation, Hayward \& McGowan 1979), and it is not hard to imagine how mechanisms might have evolved to mitigate against it.

Aside from adjusting their WMD to variations in the physical environment, some medusae are known to display diel vertical migration (DVM) in the region (Palma 1985, Mills \& Goy 1988, Andersen et al. 1992). This means that their WMD will change over the course of $24 \mathrm{~h}$. The WMD data presented here have been derived from samples collected during the day and it can be argued that the vertical segregation observed need not reflect interspecific processes. Migrating species of zooplankton generally feed maxi- 
mally at night in surface waters, and feed less during the day when they are in deeper water. Although feeding rhythms therefore tend to be tightly linked to vertical position, this is as likely to reflect the vertically stratified nature of the food environment as it is any inherent feeding rhythms per se. Although some species present a diel difference in their predation, most cnidarians seem to feed all the time (Purcell 1981a,b). So should these medusae display DVM, then it can be hypothesised that vertical segregation in a vertically stratified food environment would mitigate the influences of interspecific competition more during the day (when food is relatively scarce) than at night.

The Mediterranean Sea characterizes the remnants of one of the oldest known marine ecosystems, the Tethys Sea (Gili et al. 1998). While it currently exhibits a marked seasonality in its shallower reaches (Goy 1968, 1972), it should nevertheless be considered a fairly predictable environment. It should also be considered as historically oligotrophic, although recent human disturbance has resulted in local eutrophication. Given the historical environment of the region, and the fact that cnidarians are amongst the most primitive of metazoan animal taxa, it is conjectured that the partitioning of vertical space observed in the medusan assemblage might be a result of 'biological accommodation' (Sanders 1968) in response to pressure from predation or competition. While intraguild predation pressure has been shown to influence the numerical composition of planktonic cnidarian assemblages (Purcell 1991), it is difficult to interpret the pattern of vertical segregation here in terms of predation ${ }^{1}$. Only the 2 dominant species observed feed primarily on other medusae (Solmundella bitentaculata and Solmaris flavescens, Purcell \& Mills 1988); 1 species per seasonal group. While these species displayed patterns of vertical distribution that were mostly different from those of their prey (Table 3), they were not widely separated as might be expected if predation were responsible for structure (e.g. pelagic fishes and vertically migrating zooplankton). Rather, the findings suggest that planktonic cnidarian assemblages might have been structured by competition. Indirect evidence to support this hypothesis can be found in the differential migration patterns of some of the dominant species (Palma 1985, Andersen et al. 1992), as well as in their temporal separation (e.g. Gili et al. 1987). Chaetognaths occupy a similar trophic position to many hydromedusae, and in the western Mediterranean Sea, there

\footnotetext{
${ }^{1}$ Although medusae are known to be included amonst the prey items of some fishes (Arai 1988), information on their significance in the western Mediterranean Sea is missing. Consequently, these predators are assumed to exert a constant pressure on all members of the assemblage.
}

is evidence to suggest that the dominant species may partition vertical space over 24 h (Figs. $4 b, 5 b \& 6 b$ in Pearre 1974). In cases of overlap, the chaetognath species in question have distinctly different diets (Pearre 1974), which suggests that mechanisms to allow coexistence among low-order carnivores in the region may have evolved in other taxa too.

The findings presented here are the first to demonstrate that the vertical structure of zooplankton assemblages may be maintained despite seasonal changes in both the environment and the composition of the assemblage. That such evidence about the relative stability of the assemblages should be forthcoming from an ancient and carnivorous taxon living in an ancient, relatively stable yet seasonal environment is important. Pressures of competition amongst planktonic carnivores are likely to be easier to detect than amongst herbivores, owing to the very nature of the quantitative and qualitative food supply. The cnidarians are an old taxon, and so environmental pressures should have had time to exert their influence, if influence was to be exerted (rates of evolutionary change amongst zooplankton are unknown). The Mediterranean Sea represents an old ecosystem, whose geographic position lends it stability. In other words, it is unlikely that such patterns of temporal persistence to vertical assemblage structure would have been readily observed in other zooplankton taxa. Therefore, it should be realised that changes in the environment do influence the structure of the assemblage in non-structured ways, in the sense that they add or take away rare and very episodic species. However, the structure of the core assemblage appears resistant to the seasonal changes observed here.

Acknowledgements. We wish to thank J. Coy, P. Nival, A. Richardson and 3 anonymous reviewers for their critical comments on previous versions of the manuscript. We are grateful to $\mathrm{R}$. Charra for helping to collect the hydrological measurements in 1995, and to R. Fassi for his technical co-operation during sampling. The Coastal and Marine Management is gratefully acknowledged for its logistical support. Financial support for E. B. was provided by the Singer Polignac Foundation.

\section{LITERATURE CITED}

Alldredge A (1984) The significance of gelatinous zooplankton as pelagic consumers. In: Fasham $M$ (ed) Flow of energy and materials in marine ecosystems: theory and practice. Plenum Press, New York, p 407-433

Ambler JW, Miller CB (1987) Vertical habitat-partitioning by copepodites, adults of subtropical oceanic copepods. Mar Biol 94:561-577

Andersen V. Sardou J, Nival P (1992) The diel migrations and vertical distributions of zooplankton and micronekton in the Northwestern Mediterranean Sea. II. Siphonophores, 
hydromedusae and pyrosomids. I Plankton Res 14 $1155-1169$

Arai MN (1988) Interactions on fish and pelagic coelenterates. Can J Zool 66:1913-1927

Arai MN (1992) Active, passive factors affecting aggregations of hydromedusae: a review. Sci Mar 56:99-108

Barange M, Gibbons MJ, Carola M (1991) Diet, feeding of Euphausia hanseni, Nematoscelis megalops (Euphausiacea) in the northern Benguela Current: ecological significance of vertical space partitioning. Mar Ecol Prog Ser 73: $173-181$

Béthoux JP, Prieur L, Bong JH (1988) Le courant Ligure au large de Nice. Oceanol Acta 9:59-67

Brewer RH, Feingold JS (1991) The effect of temperature on the benthic stages of Cynea (Cnidaria: Scyphozoa), their seasonal distribution in the Niantic River estuary, Connecticut. J Exp Mar Biol Ecol 152:49-60

Brinkmann-Voss A (1987) Seasonal distribution of hydromedusae (Cnidaria, Hydrozoa) from the Gulf of Naples and vicinity, with observations on sexual and asexual reproduction in some species. In: Bouillon J, Boero F, Cicogna F, Cornelius PSF (eds) Modern trends in the systematics, ecology, evolution of hydroids, hydromedusae. Clarendon, Oxford, p 133-141

Buecher E (1996) Etude écologique des carnivores gélatineux-hydroméduses, siphonophores, scyphoméduses et cténaires-dans la rade de Villefranche-sur-Mer. PhD thesis, University of Paris VI

Buecher E, Gasser B (1998) Estimation of predatory impact of Pleurobrachia rhodopis (Cydippid Ctenophore) in the north western Mediterranean Sea: in situ observations, laboratory experiments. J Plankton Res 20:631-651

Buecher E, Goy J. Planque B, Etienne M, Dallot S (1997) Long-term fluctuations of Liriope tetraphylla in Villefranche Bay between 1966 and 1993 compared to Pelagia noctiluca fluctuations. Oceanol Acta 20:145-157

Clarke KR, Warwick RM (1994) Change in marine communities: an approach to statistical analysis, interpretation. Plymouth Marine Laboratory, Plymouth, UK

Etienne M, Corre MC, Dallot S, Nival P (1991) Observations hydrologiques à une station côtière méditerranéenne. Point B-Rade de Villefranche-sur-Mer $\left(43^{\circ} 41^{\prime} 10^{\prime \prime} \mathrm{N}\right.$ 7०19' 00" E). Campagnes Océanogr Fr (Ifremer) 14:1-89

Field JG, Clarke KR, Warwick RM (1982) A practical strategy for analysing multispecies distribution patterns. Mar Ecol Prog Ser 8:37-52

Flock ME, Hopkins TL (1992) Species composition, vertical distribution, food habits of the sergestid shrimp assemblage in the eastern Gulf of Mexico. J Crustac Biol 12: $210-233$

Gibbons MJ (1994) Diel vertical migration and feeding of Sagitta friderici and Sagitta tasmanica in the southern Benguela upwelling region, with a comment on the structure of the guild of carnivores. Mar Ecol Prog Ser 111. $225-240$

Gibbons MJ, Hutchings L (1996) Zooplankton diversity and community structure around southern Africa with special attention to the Benguela upwelling system. S Afr J Sci 92: 63-76

Gili JM, Pagès F, Vives F (1987) Distribution, ecology of a population of planktonic cnidarians in the Western Mediterranean. In: Bouillon J, Boero F, Cicogna F, Cornelius PSF (eds) Modern trends in the systematics, ecology, evolution of hydroids, hydromedusae. Clarendon, Oxford, p 157-170

Gili JM, Bouillon J, Pagès F, Palanques A, Puig P, Heusser, S (1998) Origin and biogeography of the deep-water
Mediterranean Hydromedusae including the description of two new species collected in submarine canyons of Northwestern Mediterranean. Sci Mar 62:113-134

Gostan J (1968) Contribution à l'étude hydrologique du bassin Liguro-provençal entre la Riviera et la Corse: distribution et variations saisonnières de la température, de la salinité, et de l'oxygène et des phosphates minéraux dissous dans les masses d'eau superficielles, intermédiaires et profondes. PhD thesis, University of Paris VI

Goy J (1968) Les Hydroméduses de la rade de Villefranchesur-Mer et de la mer de Ligurie. PhD thesis, University of Paris VI

Goy J (1972) Les Hydroméduses de la mer Ligure. Bull Mus Natl Hist Nat, Zool 62:61-66

Goy J (1987) Summer submergence of Persa incolorata McCrady, 1857 (Cnidaria, Hydromedusa) in the Mediterranean. Ann Inst Océanogr, Paris 63:47-56

Goy J (1997) The medusae (Cnidaria, Hydrozoa), their trophic environment: an example in the north-western Mediterranean. Ann Inst Océanogr, Paris 73:159-172

Hayward TL, McGowan JA (1979) Pattern, structure in an oceanic zooplankton community. Am Zool 19:1045-1055

Hopkins TL, Gartner JV (1992) Resource-partitioning, predation impact of a low-latitude myctophid community. Mar Biol 114:185-197

Hutchinson GE (1961) The paradox of the plankton. Am Nat 95:137-147

Longhurst AR (1985) Relationship between diversity and the vertical structure of the upper ocean. Deep-Sea Res 32: $1535-1570$

Longhurst AR (1995) Seasonal cycles of pelagic production, consumption. Progr Oceanogr 36:77-167

Mackie GO, Pugh PR, Purcell JE (1987) Siphonophore biology. Adv Mar Biol 24:97-262

McGowan JA, Walker PW (1979) Structure in the copepod community of the north Pacific gyre. Ecol Monogr 49: $195-226$

Mills CE (1995) Medusae, siphonophores and ctenophores as planktivorous predators in changing global ecosystems. ICES J Mar Sci 52:575-581

Mills, CE, Goy J (1988) In situ observations of the behavior of mesopelagic Solmissus Narcomedusae (Cnidaria, Hydrozoa). Bull Mar Sci 43:739-751

Palma SG (1985) Migración nictemeral del macroplancton gelatinoso de la bahía de Villefranche-sur-Mer, Mediterráneo Noroccidental. Invest Pesq 49:261-274

Pearre S (1974) Ecological studies of three west-Mediterranean chaetognaths. Invest Pesq 38:325-369

Picard J (1958) Origines et affinités de la faune d'Hydropolypes (Gymnoblastes et Calyptoblastes) et d'Hydroméduses (Anthoméduses et Léptoméduses) de la Méditerrannée. Rapp Réun Comm Int Expl Sci Mer Médit 14 $185-186$

Purcell JE (1981a) Feeding ecology of Rhizophysa eysenhardti, a siphonophore predator of fish larvae. Limnol Oceanogr 26:424-432

Purcell JE (1981b) Dietary composition and diel feeding patterns of epipelagic siphonophores. Mar Biol 65:83-90

Purcell JE (1991) A review of cnidarians and ctenophores feeding on competitors in the plankton. Hydrobiologia 216/217:335-342

Purcell JE, Mills CE (1988) The correlation between nematocyst types and diets in pelagic hydrozoa. In: Hessinger $D A$, Lenhoff $\mathrm{H}$ (eds) The biology of nematocysts. Academic Press, New York p 463-485

Roe HSJ, Angel MV, Badcock J, Domanski P, James PT, Pugh PR, Thurston MH (1984) The diel migrations, distributions 
within a mesopelagic community in the North East Atlantic. 1. Introduction, sampling procedures. Prog Oceanogr 13:189-199

Roger C (1973) Recherches sur la situation trophique d'un groupe d'organismes pélagiques (Euphausiacea). II. Comportements nutritionnels. Mar Biol 18:317-320

Roger C (1975) Rythmes nutritionnels et organisation d'une population de crustacés pélagiques (Euphausiacea). Mar Biol 32:365-378

Sanders HL (1968) Marine benthic diversity: a comparative study. Am Nat 102:243-282

Vives F (1966) Zooplancton nerítico de las aguas de Castellón (Mediterráneo occidental). Invest Pesq 30:49-166

Editorial responsibility: Jennifer Purcell, (Contributing Editor) Cambridge, Maryland, USA
Werner B (1958) Die Verbreitung und das jahreszeitliche Auftreten der Anthomeduse Rathkea octopunctata $M$. Sars, sowie die Temperaturabhängigkeit ihrer Entwicklung und Fortplanzung. Helgol Wiss Meeresunters 6: $137-170$

Werner B (1961) Morphologie und Lebensgeschichte, sowie Temperaturabhängigkeit der Verbreitung und des jahreszeitlichen Auftretens von Bougainvillia superciliaris (L Agassiz). Helgol Wiss Meeresunters 7:206-237

Zelickman EA (1972) Distribution, ecology of the pelagic hydromedusae, siphonophores, ctenophores of the Barents Sea, based on perennial plankton collections. Mar Biol 17:256-264

Submitted: October 28, 1998; Accepted: June 11, 1999 Proofs received from author(s): November 2, 1999 